\title{
Eosinophilic and classic chromophobe renal cell carcinomas have similar frequent losses of multiple chromosomes from among chromosomes 1, 2, 6, 10, and 17, and this pattern of genetic abnormality is not present in renal oncocytoma
}

\author{
Matteo Brunelli, ${ }^{1,2}$, John N Eble ${ }^{1}$, Shaobo Zhang ${ }^{1}$, Guido Martignoni ${ }^{2,3}$, Brett Delahunt ${ }^{4}$ \\ and Liang Cheng ${ }^{1,5}$
}

${ }^{1}$ Department of Pathology and Laboratory Medicine; ${ }^{2}$ Dipartimento di Patologia, Universitá di Verona, Verona, Italy; ${ }^{3}$ Dipartimento di Patologia, Universitá di Sassari, Sassari, Italy; ${ }^{4}$ Department of Pathology and Molecular Medicine, Wellington Medical School, Wellington, New Zealand and ${ }^{5}$ Department of Urology, Indiana University School of Medicine, Indianapolis, IN, USA

\begin{abstract}
That chromophobe renal cell carcinoma has an uncommon eosinophilic variant has been recognized for more than a decade. In sections stained with hematoxylin and eosin, the eosinophilic variant of chromophobe renal cell carcinoma and renal oncocytoma are similar in appearance. While it is well established that chromophobe renal cell carcinoma and renal oncocytoma have different patterns of genetic anomalies, little is known of the genetics of the eosinophilic variant of chromophobe renal cell carcinoma. This study was undertaken to elucidate the genetic lesions of eosinophilic chromophobe renal cell carcinoma and to compare them with those found in classic chromophobe renal cell carcinoma and in renal oncocytoma. A total of 29 renal neoplasms-nine eosinophilic chromophobe renal cell carcinomas, 10 classic chromophobe renal cell carcinomas, and 10 oncocytomas-were investigated by fluorescence in situ hybridization on $5 \mu \mathrm{m}$ paraffinembedded tissue sections with centromeric probes for chromosomes 1, 2, 6, 10, and 17. Signals were counted in 100-200 neoplastic nuclei from each tumor. Chromophobe renal cell carcinomas frequently showed loss of chromosomes 1 (70\% of classic, $67 \%$ of eosinophilic), 2 (90\% classic, $56 \%$ eosinophilic), 6 ( $80 \%$ classic, $56 \%$ eosinophilic), 10 (60\% classic, 44\% eosinophilic), and 17 ( $90 \%$ classic, 78\% eosinophilic); Among the classic chromophobe renal cell carcinomas, only one had no loss of any of the chromosomes, while $50 \%$ had loss of all five chromosomes. Among the eosinophilic chromophobe renal cell carcinomas, one of nine had no loss and $44 \%$ had loss of all five chromosomes. One oncocytoma had loss of chromosome 1 . No other chromosomal loss was detected in the oncocytomas. In conclusion, losses of chromosomes 1, 2, 6, 10, and 17 are frequent in both eosinophilic and classic chromophobe renal cell carcinomas. Loss of chromosome 1 occurs occasionally in oncocytoma but losses of chromosomes 2, 6, 10, and 17 are not found in oncocytomas. When the differential diagnostic problem is oncocytoma vs eosinophilic chromophobe renal cell carcinoma, detection of losses of chromosomes 2, 6, 10, or 17 effectively excludes the diagnosis of oncocytoma and supports the diagnosis of chromophobe renal cell carcinoma.
\end{abstract}

Modern Pathology (2005) 18, 161-169, advance online publication, 1 October 2004; doi:10.1038/modpathol.3800286

Keywords: fluorescence in situ hybridization; chromophobe renal cell carcinoma; renal oncocytoma; differential diagnosis

Correspondence: Dr JN Eble, MD, Department of Pathology and Laboratory Medicine, Medical Science Building room A128, 635 Barnhill Drive, Indianapolis, IN 46202-5120, USA.

E-mail: jeble@iupui.edu

Received 15 July 2004; revised and accepted 18 August 2004; published online 1 October 2004
While chromophobe renal cell carcinoma was first recognized as a distinct type of renal cell carcinoma in $1985^{1}$ and was given its name because the cytoplasm of the cells was pale, in 1988 Thoenes et $a l^{2}$ recognized that it has an eosinophilic variant. Cells with eosinophilic cytoplasm commonly are 
present in classic chromophobe renal cell carcinomas and the designation of the eosinophilic variant has been reserved for tumors composed either exclusively or predominantly of cells with eosinophilic cytoplasm. In sections stained with hematoxylin and eosin, these tumors closely resemble renal oncocytomas, posing a diagnostic challenge.

It has been known since 1992 that chromophobe renal cell carcinomas often have multiple losses of whole chromosomes, most frequently Y, 1, 2, 6, 10, 13, 17, and $21 .^{3}$ These genetic losses have been found by classical cytogenetic methods, ${ }^{3-6}$ comparative genomic hybridization, ${ }^{7,8}$ and restriction fragment length polymorphism analysis. ${ }^{9}$ The losses are sometimes so substantial that they can be detected by DNA flow cytometry. ${ }^{10-12}$ Fluorescence in situ hybridization methods have been applied to only a few chromophobe renal cell carcinomas. Iqbal et $a l^{13}$ used noncentromeric probes on touch imprint smears from six chromophobe renal cell carcinomas and found variable percentages of nuclei giving single signals. The chromophobe renal cell carcinomas studied by fluorescence in situ hybridization in other papers gave mixed results. ${ }^{14-16}$ Renal oncocytomas have two common patterns of genetic abnormality: rearrangements involving $11 \mathrm{q} 13^{17,18}$ and loss of chromosomes Y and 1. ${ }^{19-21}$ Morphologic similarities and these common losses of chromosomes have prompted some authors to suggest that there is a close relationship between chromophobe renal cell carcinoma and renal oncocytoma, particularly in cases in which there are large numbers of tumors and in the Birt-Hogg-Dubé syndrome. ${ }^{22-24}$ However, no genetic study has compared eosinophilic chromophobe renal cell carcinoma with typical chromophobe renal cell carcinoma, or with renal oncocytoma. The present study was undertaken to make this comparison and to test the hypothesis that the eosinophilic variant of chromophobe renal cell carcinoma is an entity linking classic chromophobe renal cell carcinoma with renal oncocytoma.

\section{Materials and methods}

\section{Tissue Samples}

Paraffin blocks from nine solitary sporadic eosinophilic chromophobe renal cell carcinomas, 10 solitary sporadic classic chromophobe renal cell carcinomas, and 10 solitary sporadic oncocytomas were selected from the files of the Department of Pathology of the University of Verona, Verona, Italy, the Department of Pathology and Molecular Medicine, Wellington Medical School, Wellington, New Zealand, and the consultation files of one of the authors (JNE). All of the tumors were in nephrectomy specimens. All available slides were reviewed by four of the authors (MB, BD, JNE, GM). Classic chromophobe renal cell carcinomas had the appearance typical of chromophobe renal cell carcinoma in sections stained with hematoxylin and eosin and had a positive reaction with the Hale's colloidal iron stain (Figure 1a and b). Eosinophilic chromophobe renal cell carcinomas were defined as tumors that had diffuse positive reactions with the Hale's colloidal iron stain and that, in the opinions of the authors, could be mistaken for renal oncocytoma in sections stained with hematoxylin and eosin (Figure 1c and d). Renal oncocytomas had the appearance typical of renal oncocytoma and negative reactions with Hale's colloidal iron stain (Figure 1e and f). The examples of classic chromophobe renal cell carcinoma and renal oncocytoma were selected to be typical examples of those entities. The eosinophilic chromophobe renal cell carcinomas were drawn from a large series of chromophobe renal cell carcinomas, of which they made up approximately $10 \%{ }^{25}$

\section{Fluorescence In Situ Hybridization}

Chromosomes 1, 2, 6, 10, and 17 were selected for this study because they are the chromosomes most frequently found to be lost in previous studies of chromophobe renal cell carcinoma and because of the availability of centromeric probes specific for each of them. The Y chromosome was not used because of its absence from tumors arising in women and because its normal copy number of 1 introduces different analytical considerations from the others. As previously described, ${ }^{26,27}$ five $\mu \mathrm{m}$ sections were cut from paraffin-embedded blocks of tissue. The paraffin was removed from the sections with two 10min washes in xylene. After hydrating in 100, 85, and $70 \%$ ethanol solutions $(10 \mathrm{~min})$, rinsing in distilled water $(10 \mathrm{~min})$, and twice in phosphate buffer solution ( $\mathrm{pH} 7,10 \mathrm{~min}$ each), the slides were fixed in methanol-acetic acid 3:1 for $10 \mathrm{~min}$ and air dried. Next, the sections were treated in a $2 \times$ standard saline citrate solution for $15 \mathrm{~min}$ at $37^{\circ} \mathrm{C}$, and then dehydrated in consecutive 70,85 , and $100 \%$ ethanol solutions for $1 \mathrm{~min}$ each and then dried. Next, the sections were bathed in $0.1 \mathrm{mM}$ citric acid (pH 6) solution at $85^{\circ} \mathrm{C}$ for $1 \mathrm{~h}$. Then they were again dehydrated in a series of ethanol solutions and dried. The tissue was digested by applying $0.75 \mathrm{ml}$ of pepsin (Sigma, St Louis, MO, USA) solution ( $4 \mathrm{mg} / \mathrm{ml}$ in $0.9 \% \mathrm{NaCl}, \mathrm{pH} 1.5)$ to each slide and incubating the slides in a humidified box for $30 \mathrm{~min}$ at $37^{\circ} \mathrm{C}$. Next, the slides were rinsed with distilled water for a few seconds, dehydrated again in graded ethanol solutions and dried. Centromeric probes for chromosomes 1, 2, 6, 10, and 17 (Vysis, Downers Grove, IL, USA) were used. Each probe was diluted 1:50 in tDenHyb1 buffer (Insitus, Albuquerque, NM, USA). In all, $10 \mu \mathrm{l}$ of diluted probe was applied to each slide and cover slips were placed over the slides. Denaturation was achieved by incubating the slides at $80^{\circ} \mathrm{C}$ for $10 \mathrm{~min}$ in a humidified box; then hybridization was carried 

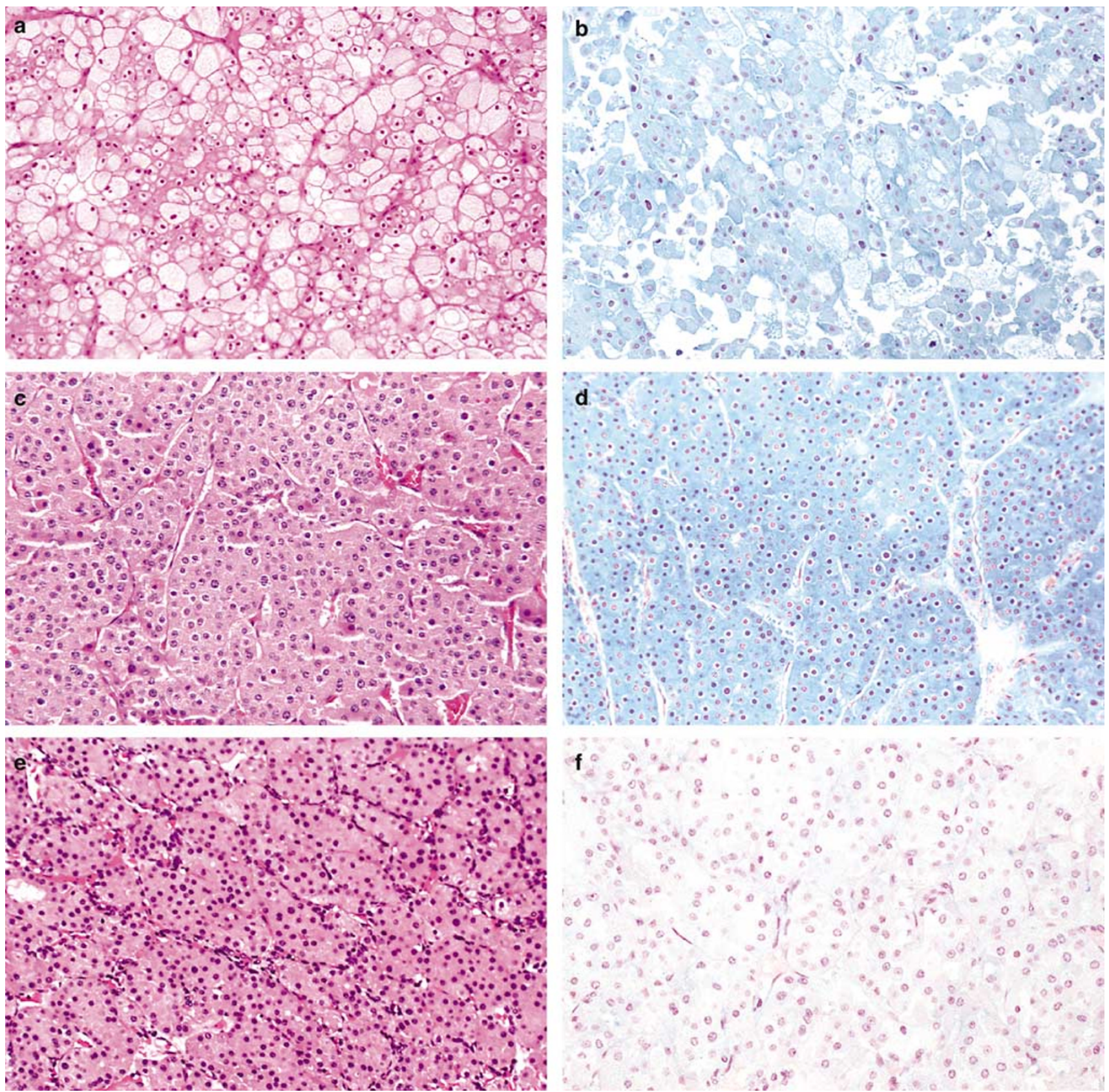

Figure 1 (a) Classic chromophobe renal cell carcinoma, (b) Classic chromophobe renal cell carcinoma with diffusely positive cytoplasmic reaction with Hale's colloidal iron stain. (c) Eosinophilic chromophobe renal cell carcinoma. (d) Eosinophilic chromophobe renal cell carcinoma with diffusely positive cytoplasmic reaction with Hale's colloidal iron stain. (e) Oncocytoma. (f) Oncocytoma with diffusely negative cytoplasmic reaction with Hale's colloidal iron stain.

out at $37^{\circ} \mathrm{C}$ for $3 \mathrm{~h}$. The coverslips were then removed and the slides were immersed at room temperature in $0.5 \times$ SSC for $2 \mathrm{~min}$, in $50 \%$ formamide $/ 1 \times$ SSC for $5 \mathrm{~min}$, and in $2 \times$ SSC for $2 \mathrm{~min}$. The slides were air dried and counterstained with $10 \mathrm{l}$ DAPI/Antifade (DAPI in Fluorguard, $0.5 \mathrm{~g} / \mathrm{ml}$, Insitus, Albuquerque, NM, USA).

The slides were examined using an Olympus IX-50 microscope (Olympus, Tokyo, Japan) with the following filters: blue filter cube (Arcturus, Mountain View, CA, USA) for SpectrumGreen (centromeric 6, 10, and 17) Vysis probes, SpectrumOrange Filter (Chroma, Brattleboro, VT, USA) for SpectrumOrange (centromeric 1 and 2) Vysis probes, and the UV Filter (Chroma, Brattleboro, VT, USA) for the DAPI nuclear counterstain. The signals were recorded with a CCD camera. 
Table 1 Percentages of different signal numbers in nuclei from normal tissue

No. case $\frac{\text { Chromosome } 1}{\text { Percentage of nuclei }} \frac{\text { Chromosome } 2}{\text { Percentage of nuclei }} \frac{\text { Chromosome } 6}{\text { Percentage of nuclei }} \frac{\text { Chromosome } 10}{\text { Percentage of nuclei }} \frac{\text { Chromosome } 17}{\text { Percentage of nuclei }}$

\begin{tabular}{lrrrrrrrr}
\multicolumn{2}{l}{ Normal } \\
1
\end{tabular}

\begin{tabular}{llllllllll}
\multicolumn{6}{c}{ Normal tissue adjacent } \\
1
\end{tabular}

$\begin{array}{rlrrrr}15 & 80 & 5 & 15 & 81 & 4 \\ 10 & 83 & 7 & 9 & 86 & 5 \\ 11 & 87 & 2 & 11 & 86 & 3 \\ 11 & 87 & 2 & 10 & 86 & 4 \\ 9 & 87 & 4 & 17 & 81 & 2 \\ 11 & 87 & 2 & 7 & 88 & 5 \\ 7 & 88 & 5 & 20 & 80 & 0 \\ 11 & 86 & 3 & 15 & 80 & 5 \\ 9 & 87 & 4 & 10 & 86 & 4 \\ 15 & 84 & 1 & 14 & 84 & 2\end{array}$

\begin{tabular}{|c|c|c|c|c|c|c|c|c|c|c|c|c|c|c|c|}
\hline 1 & 18 & 80 & 2 & 15 & 80 & 5 & 11 & 87 & 2 & 20 & 80 & 0 & 20 & 79 & 1 \\
\hline 2 & 11 & 80 & 9 & 7 & 88 & 5 & 11 & 87 & 2 & 7 & 88 & 5 & 10 & 86 & 4 \\
\hline 3 & 11 & 86 & 3 & 18 & 80 & 2 & 10 & 86 & 4 & 11 & 87 & 2 & 11 & 86 & 3 \\
\hline 4 & 16 & 83 & 1 & 15 & 80 & 5 & 10 & 85 & 5 & 11 & 87 & 2 & 10 & 86 & 4 \\
\hline 5 & 10 & 84 & 6 & 10 & 84 & 6 & 15 & 84 & 1 & 9 & 87 & 4 & 20 & 80 & 0 \\
\hline 6 & 14 & 76 & 10 & 13 & 86 & 1 & 10 & 83 & 7 & 11 & 87 & 2 & 7 & 88 & 5 \\
\hline 7 & 10 & 83 & 7 & 11 & 86 & 3 & 15 & 80 & 5 & 15 & 80 & 5 & 19 & 72 & 9 \\
\hline 8 & 11 & 87 & 2 & 9 & 87 & 4 & 9 & 87 & 4 & 11 & 86 & 3 & 14 & 80 & 6 \\
\hline 9 & 20 & 80 & 0 & 9 & 84 & 7 & 14 & 76 & 10 & 20 & 80 & 0 & 8 & 87 & 5 \\
\hline 10 & 14 & 84 & 2 & 16 & 83 & 1 & 13 & 81 & 6 & 15 & 84 & 1 & 12 & 84 & 4 \\
\hline
\end{tabular}

\section{In Situ Hybridization Analysis}

The criteria for evaluating the fluorescence in situ hybridization signals were adapted from Hopman et $a .^{28,29}$ From 100 to 200 nuclei were scored for alpha-satellite signals observed with the fluorescence microscope at $\times 400$ magnification. As much as possible, signals from solitary nuclei were counted; however, groups of two or three adjacent (but not overlapping) nuclei were occasionally included in the counts. Nuclei were counted when the entire nuclear circumference had a round-tooval contour and showed no evidence of fragmentation. Two signals of the same size in close proximity, not connected by a link, were counted as two signals. A diffuse signal was regarded as a signal if it was contiguous and within an acceptable boundary. Two small signals connected by a visible link were counted as one signal. Overlapping nuclei and nuclei with uncertain signals were not counted. There was no significant variation in hybridization efficiency when different areas of the slides were examined. The number of signals visualized in the nuclei were tabulated from randomly selected areas of the slides in which nuclear overlap was minimal.

\section{Statistical Analysis}

Fisher's exact test was used to compare the proportion of chromosomal loss among the different types of tumors. Pairwise comparison was made using the Sidak adjustment method to control the overall significance level of the tests.

\section{Results}

To determine the performance of the system and establish the distribution of signals in nuclei from normal tissue, non-neoplastic kidney tissues from 25 of the blocks containing tumors were studied. This approach has the advantages that section thickness and tissue processing parameters were the same for the normal samples as for the tumors. The results are presented in Table 1 . The data from the normal tissue are quite uniform. For chromosomes 1,2 , and 6 the mean percentage of nuclei with two signals was $83 \%$ and for chromosomes 10 and 17 , it was 85 and $84 \%$, respectively. The standard deviations of the mean numbers of nuclei with two signals for chromosomes 1, 2, 6, 10, and 17 were $3.39,3.12,3.71,2.94$, and 3.91 , respectively. For 
Table 2 Percentages of nuclei with different numbers of signals from neoplastic cells

No. case $\frac{\text { Chromosome } 1}{\text { Percentage of nuclei }} \frac{\text { Chromosome } 2}{\text { Percentage of nuclei }} \frac{\text { Chromosome } 6}{\text { Percentage of nuclei }} \frac{\text { Chromosome 10 }}{\text { Percentage of nuclei }} \frac{\text { Chromosome } 17}{\text { Percentage of nuclei }}$

\begin{tabular}{lrrrrrr}
\multicolumn{6}{l}{ Classic variant } & chromopho renal cell carcinoma \\
1 & 82 & 17 & 1 & 88 & 9 & 3 \\
2 & 10 & 88 & 2 & 84 & 12 & 4 \\
3 & 91 & 9 & 0 & 88 & 10 & 2 \\
4 & 15 & 82 & 3 & 16 & 82 & 2 \\
5 & 16 & 83 & 1 & 90 & 9 & 1 \\
6 & 83 & 14 & 3 & 78 & 16 & 6 \\
7 & 89 & 9 & 2 & 84 & 14 & 2 \\
8 & 87 & 9 & 4 & 88 & 10 & 2 \\
9 & 90 & 10 & 0 & 82 & 15 & 3 \\
10 & 87 & 13 & 0 & 80 & 15 & 5
\end{tabular}

Eosinophilic variant chromophobe renal cell carcinoma

$\begin{array}{rrrrrrr}1 & 83 & 11 & 6 & 81 & 18 & 1 \\ 2 & 10 & 84 & 6 & 14 & 86 & 0 \\ 3 & 88 & 11 & 1 & 79 & 16 & 5 \\ 4 & 83 & 11 & 6 & 80 & 18 & 2 \\ 5 & 12 & 82 & 6 & 17 & 79 & 4 \\ 6 & 89 & 11 & 0 & 85 & 10 & 5 \\ 7 & 89 & 9 & 2 & 91 & 8 & 1 \\ 8 & 8 & 90 & 2 & 16 & 84 & 0 \\ 9 & 86 & 10 & 4 & 4 & 41 & 55\end{array}$

89
84
10
14
84
82
90
91
80
84

$\begin{array}{rr}10 & 1 \\ 12 & 4 \\ 88 & 2 \\ 82 & 4 \\ 12 & 4 \\ 16 & 2 \\ 10 & 0 \\ 9 & 0 \\ 16 & 4 \\ 16 & \end{array}$

82
5
84
18
15
86
79
82
11
82

$\begin{array}{ll}17 & 1 \\ 93 & 2 \\ 15 & 1 \\ 78 & 4 \\ 82 & 3 \\ 13 & 1 \\ 20 & 1 \\ 17 & 1 \\ 87 & 2 \\ 15 & 3\end{array}$

$\begin{array}{lrr}81 & 18 & 1 \\ 47 & 51 & 2 \\ 82 & 17 & 1 \\ 18 & 82 & 0 \\ 70 & 26 & 4 \\ 88 & 2 & 10 \\ 89 & 11 & 0 \\ 83 & 16 & 1 \\ 83 & 14 & 3 \\ 87 & 12 & 1\end{array}$

\section{Renal oncocytoma}

\begin{tabular}{lrl}
1 & 12 & 85 \\
2 & 9 & 90 \\
3 & 11 & 88 \\
4 & 7 & 89 \\
5 & 6 & 90 \\
6 & 14 & 83 \\
7 & 12 & 87 \\
8 & 12 & 85 \\
9 & 75 & 18 \\
10 & 12 & 85 \\
\hline
\end{tabular}

$\begin{array}{lr}3 & 1 \\ 1 & 15 \\ 1 & \\ 4 & \\ 4 & 11 \\ 3 & \\ 1 & 11 \\ 3 & \\ 7 & 11 \\ 3 & 12\end{array}$

$\begin{array}{rll}16 & 84 & 0 \\ 15 & 83 & 2 \\ 8 & 91 & 1 \\ 3 & 94 & 3 \\ 11 & 88 & 1 \\ 7 & 89 & 4 \\ 11 & 86 & 3 \\ 9 & 86 & 5 \\ 11 & 87 & 2 \\ 12 & 88 & 0\end{array}$

76
15
89
79
11
8
79
15

$\begin{array}{rr}18 & 6 \\ 85 & 0 \\ 6 & 5 \\ 16 & 5 \\ 88 & 1 \\ 10 & 6 \\ 17 & 4 \\ 84 & 1 \\ 24 & 72\end{array}$

$\begin{array}{rr}86 & 11 \\ 12 & 82 \\ 76 & 15 \\ 90 & 7 \\ 8 & 86 \\ 84 & 12 \\ 16 & 81 \\ 11 & 83 \\ 1 & 44\end{array}$

$\begin{array}{rlll}3 & 81 & 19 & 0 \\ 6 & 46 & 52 & 2 \\ 9 & 88 & 12 & 0 \\ 3 & 79 & 20 & 1 \\ 6 & 55 & 44 & 1 \\ 4 & 49 & 49 & 2 \\ 3 & 16 & 83 & 1 \\ 6 & 16 & 82 & 2 \\ 55 & 88 & 11 & 1\end{array}$

$\begin{array}{llrlllll}82 & 0 & 14 & 86 & 0 & 27 & 72 & 1 \\ 88 & 1 & 20 & 79 & 1 & 14 & 84 & 2 \\ 80 & 1 & 19 & 77 & 4 & 15 & 81 & 4 \\ 78 & 2 & 19 & 80 & 1 & 18 & 79 & 3 \\ 81 & 0 & 20 & 80 & 0 & 20 & 79 & 1 \\ 83 & 0 & 12 & 87 & 1 & 19 & 80 & 1 \\ 79 & 1 & 6 & 90 & 4 & 13 & 86 & 1 \\ 82 & 0 & 12 & 85 & 3 & 12 & 85 & 3 \\ 80 & 2 & 15 & 81 & 4 & 19 & 81 & 0 \\ 79 & 0 & 20 & 80 & 0 & 11 & 89 & 0\end{array}$

chromosomes 1,6 , and 10 , the mean percentage of nuclei with single signals was $12 \%$ and for chromosomes 2 and 17, it was 13\%. The standard deviations of the mean numbers of nuclei with single signals for chromosomes 1, 2, 6, 10, and 17 were $3.52,3.51,2.51,3.48$, and 4.43 , respectively. In the tumors, chromosomal loss was defined as a percentage of nuclei with single signals greater than the normal tissue mean for that chromosome +4 times the normal tissue standard deviation for that chromosome. Thus, for chromosomes 1, 2, 6, 10, and 17 , percentages of single signals greater than 26,27 , 22,26 , and $30 \%$, respectively, were considered to indicate chromosomal loss.

The results from the tumors are presented in Tables 2 and 3 . Inspection of the data in Table 1 shows that in the carcinomas when chromosomal losses are detected, they are almost always striking, with single signals detected in $75 \%$ or more of nuclei. Lesser losses, in the range of $45-60 \%$ of nuclei with single signals, were observed only 4 times and only with chromosome 17. In the oncocytomas, a few tumors had single signal counts of $20 \%$ or more; however, the oncocytoma with loss of chromosome 1 had as striking a loss as the carcinomas: $75 \%$ single signals. Losses are summarized in Table 3. Among the 10 classic chromophobe renal cell carcinomas, seven had loss of chromosome 1, nine had loss of chromosome 2 (Figure 2a), eight had loss of chromosome 6, six had loss of chromosome 10, and nine had loss of chromosome 17. Five of the 10 tumors had loss of all five of the chromosomes and one classic chromophobe renal cell carcinoma had no loss of any of the chromosomes. Among the nine eosinophilic chromophobe renal cell carcinomas, six had loss of chromosome 1; five had loss of chromosome 2; five had loss of chromosome 6; four had loss of chromosome 10; and seven had loss of chromosome 17. Four of the nine eosinophilic chromophobe renal cell carcinomas had loss of all five of the chromosomes and one had no loss of any of the chromosomes. All but one 
Table 3 Summary of losses of chromosomes 1, 2, 6, 10, and 17 in chromophobe renal C

\begin{tabular}{|c|c|c|c|c|c|}
\hline \multirow[t]{2}{*}{ Case number } & \multicolumn{5}{|c|}{ Chromosome number } \\
\hline & 1 & 2 & 6 & 10 & 17 \\
\hline \multicolumn{6}{|c|}{ Classic chromophobe renal cell carcinoma } \\
\hline 1 & Loss & Loss & Loss & Loss & Loss \\
\hline 2 & No loss & Loss & Loss & No loss & Loss \\
\hline 3 & Loss & Loss & No loss & Loss & Loss \\
\hline 4 & No loss & No loss & No loss & No loss & No loss \\
\hline 5 & No loss & Loss & Loss & No loss & Loss \\
\hline 6 & Loss & Loss & Loss & Loss & Loss \\
\hline 7 & Loss & Loss & Loss & Loss & Loss \\
\hline 8 & Loss & Loss & Loss & Loss & Loss \\
\hline 9 & Loss & Loss & Loss & No loss & Loss \\
\hline 10 & Loss & Loss & Loss & Loss & Loss \\
\hline$\%$ with loss & 70 & 90 & 80 & 60 & 90 \\
\hline \multicolumn{6}{|c|}{ Eosinophilic chromophobe renal cell carcinoma } \\
\hline 1 & Loss & Loss & Loss & Loss & Loss \\
\hline 2 & No loss & No loss & No loss & No loss & Loss \\
\hline 3 & Loss & Loss & Loss & Loss & Loss \\
\hline 4 & Loss & Loss & Loss & Loss & Loss \\
\hline 5 & No loss & No loss & No loss & No loss & Loss \\
\hline 6 & Loss & Loss & Loss & Loss & Loss \\
\hline 7 & Loss & Loss & Loss & No loss & No loss \\
\hline 8 & No loss & No loss & No loss & No loss & No loss \\
\hline 9 & Loss & No loss & No loss & No loss & Loss \\
\hline$\%$ with loss & 67 & 56 & 56 & 44 & 78 \\
\hline \multicolumn{6}{|l|}{ Oncocytoma } \\
\hline 1 & No loss & No loss & No loss & No loss & No loss \\
\hline 2 & No loss & No loss & No loss & No loss & No loss \\
\hline 3 & No loss & No loss & No loss & No loss & No loss \\
\hline 4 & No loss & No loss & No loss & No loss & No loss \\
\hline 5 & No loss & No loss & No loss & No loss & No loss \\
\hline 6 & No loss & No loss & No loss & No loss & No loss \\
\hline 7 & No loss & No loss & No loss & No loss & No loss \\
\hline 8 & No loss & No loss & No loss & No loss & No loss \\
\hline 9 & Loss & No loss & No loss & No loss & No loss \\
\hline 10 & No loss & No loss & No loss & No loss & No loss \\
\hline$\%$ with loss & 10 & 0 & 0 & 0 & 0 \\
\hline
\end{tabular}

of the renal oncocytomas showed two signals for all of the probes (Figure 2b); the exception had loss of chromosome 1.

No significant difference in the proportion of tumors with chromosomal losses was found between classic and eosinophilic chromophobe renal cell carcinomas for chromosome $1(P=1.000)$, chromosome $2(P=0.3659)$, chromosome $6 \quad(P=0.7252)$, chromosome $10 \quad(P=0.9594)$, or chromosome 17 $(P=0.9270)$.

\section{Discussion}

These data show that the eosinophilic variant of chromophobe renal cell carcinoma and classic chromophobe renal cell carcinoma have similarly highly frequent losses of chromosomes 1, 2, 6, 10, and 17 and that renal oncocytomas do not have these genetic abnormalities. Some studies have suggested, based upon morphology and some tumors with hybrid appearances in settings of oncocytomatosis and Birt-Hogg-Dubé syndrome, that chromophobe renal cell carcinoma and renal oncocytoma may be closely related..$^{22-24}$ If this is so, the connection lies elsewhere than in the most frequent chromosomal losses of chromophobe renal cell carcinoma and the data do not support the hypothesis that the eosinophilic variant of chromophobe renal cell carcinoma is a transition form between classic chromophobe renal cell carcinoma and renal oncocytoma.

Initially, a variety of genetic abnormalities, such as an interstitial deletion of the short arm of chromosome 11, trisomies of chromosomes 7, 12, 16,18 , and 20 and alteration of chromosome 11q, were reported in chromophobe renal cell carcinomas. ${ }^{19,30}$ Schwerdtle et al ${ }^{9}$ studied 11 chromophobe renal cell carcinomas and found a high frequency of loss of heterozygosity (73-91\%) at $1 p, 2 p, 6 p, 13 p$, $17 p$, and $21 q$ with a panel of nine loci and also a high frequency $(63 \%)$ of loss at chromosome $14 \mathrm{q}$ 

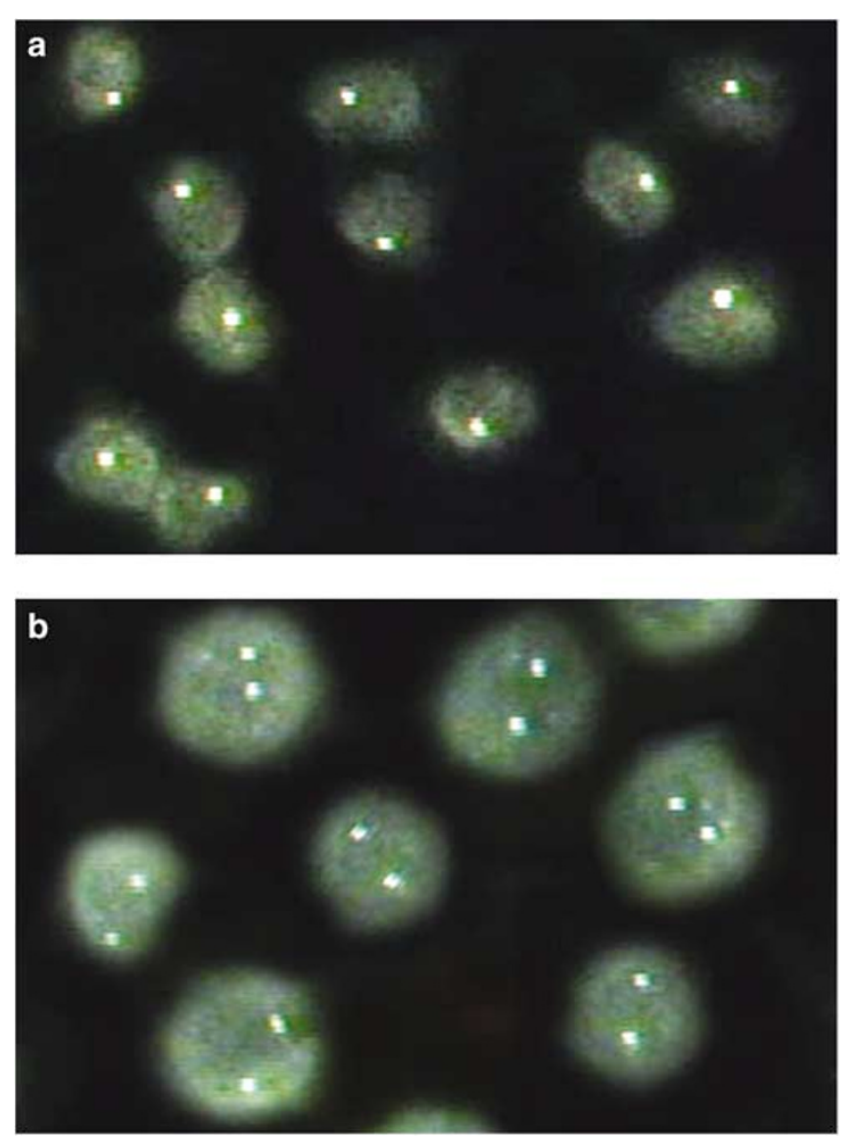

Figure 2 (a) Classic chromophobe renal cell carcinoma showing nuclei with single fluorescent signals for chromosome 2. (b) Oncocytoma showing two nuclei with two fluorescent signals for chromosome 2 .

that has not been confirmed by other studies. Speicher et $\mathrm{al}^{7}$ scanned metaphase spreads of 19 chromophobe renal cell carcinoma using comparative genomic hybridization analysis and found that losses of multiple chromosomes from among chromosomes $1,2,6,10,13,17$, and 21 is a genetic pattern occurring in most chromophobe renal cell carcinomas. These findings have been confirmed by karyotyping studies. Bugert et $a l^{31}$ analyzed 42 chromophobe renal cell carcinomas with a set of two to three microsatellite markers for each of chromosomes 1, 2, 6, 10, 13, 17, and 21 and found loss of chromosomes in up to $95 \%$ of tumors. In all but one tumor, losses of multiple chromosomes were present. Cytogenetic analysis also has shown variable losses of chromosomes in chromophobe renal cell carcinomas. ${ }^{3-6}$ A DNA cytometric analysis of 43 chromophobe renal cell carcinomas revealed an aneuploid DNA index between 1.1 and 2.1 in $77 \%$ of the cases. ${ }^{11}$ An aneuploid DNA index was found in three of five chromophobe renal cell carcinomas in another study. ${ }^{10}$ Akhtar et $a l^{32}$ found a hypodiploid DNA index varying between 0.70 and 0.90 in 24 chromophobe renal cell carcinomas. These studies did not distinguish between results from classic chromophobe renal cell carcinomas and eosinophilic ones. Iqbal et $a l^{13}$ recognized the two types but it is unclear whether eosinophilic chromophobe renal cell carcinomas were included in the study. Our results are in agreement with previous data for chromophobe renal cell carcinomas in general and for the first time demonstrate that both the classic and eosinophilic variants of chromophobe renal cell carcinoma have the same frequent losses of chromosomes 1, 2, 6, 10, and 17 .

Chromophobe renal cell carcinomas with normal complements of chromosomes are in the minority. We found two examples among 19 tumors (one classic and one eosinophilic). This is similar to what others have reported: Speicher et $a l^{7}$ found 2/19 cases, Bugert et $a l^{31} 1 / 42$, Iqbal et $a l^{13} 2 / 8$, and Verdorfer et $a l^{16} 1 / 3$. Four of the carcinomas had roughly equal populations of nuclei with single and double signals for chromosome 17.

We found heterogeneous populations with respect to chromosome 17 in four of the carcinomas. Heterogeneous populations in tumors are well recognized; in 1988, Hopman et $a l^{28}$ reported that an apparently homogeneous tumor cell population, at least with respect to DNA content, can contain fractions of cells containing chromosome numbers that deviate from the expected number. Some DNA cytometric and cytogenetic studies have observed mosaicism in chromophobe renal cell carcinomas ${ }^{4,6,33-35}$ Gunawan et $a l^{6}$ concluded that endoreduplication resulting in triploid-to-hypodiploid chromosome numbers occurs in chromophobe renal cell carcinoma.

All but one of the renal oncocytomas showed normal numbers of all the chromosomes studied and the exception showed loss only of chromosome 1. Loss of chromosome 1 in renal oncocytomas is infrequent, but has been reported before. ${ }^{20,36,37} \mathrm{We}$ observed loss of chromosome 1 at a lower frequency $(10 \%)$ than was described by Polascik et $a l^{38}(57 \%$ $\mathrm{LOH}$ at $1 \mathrm{p}$ and $30 \% \mathrm{LOH}$ at $1 \mathrm{q}$ on 13 cases), Crotty et $a l^{19}$ (33\%, karyotyping study on six cases), Presti et $a l^{37}$ (45\%, CGH study on 13 cases), Thrash-Bingham et $a l^{39}(75 \%, \mathrm{LOH}$ at $1 \mathrm{p}$ on four cases), and Brown et $a l^{36}$ (50\%, FISH study on 20 cases), but exactly the same as Herbers et $a l^{40}(10 \%, \mathrm{LOH}$ with two markers on $1 \mathrm{p} / 1 \mathrm{q}$ in a study performed on 41 cases). The differences may be attributable to our use of centromeric probes to detect losses of whole chromosomes, while some of the other studies used methods that detect partial losses of chromosomes.

In summary, we found with interphase cytogenetics that eosinophilic and classic chromophobe renal cell carcinomas have similarly frequent losses of chromosomes 1, 2, 6, 10, and 17 and renal oncocytomas usually show normal complements of these chromosomes, with occasional loss of chromosome 1. This does not lend support to the hypothesis that chromophobe renal cell carcinoma and renal oncocytoma are closely related, or that eosinophilic chromophobe renal cell carcinoma is a 
transition form between chromophobe renal cell carcinoma and renal oncocytoma. In the differential diagnostic context of renal oncocytoma vs eosinophilic chromophobe renal cell carcinoma, loss of chromosomes $2,6,10$, or 17 is a helpful marker of eosinophilic chromophobe renal cell carcinoma, supplementing Hale's colloidal iron stain, which some laboratories find difficult to perform. Unfortunately, the method is less to be helpful with needle biopsies because they may not afford the number of sections needed or may not contain enough nuclei for the FISH analysis.

\section{Acknowledgements}

This paper was presented in part at the 2003 annual meeting of the US and Canadian Academy of Pathology. This work was supported in part by Fondazione Cassa di Risparmio di Verona (Bando, 2001), Banco di Sardegna (2003), AIRC, Milan, MIUR, Diagnostica Molecolare in Oncologia (2003).

\section{References}

1 Thoenes W, Störkel S, Rumpelt H-J. Human chromophobe cell renal carcinoma. Virchows Arch (B) 1985; 48:207-217.

2 Thoenes W, Störkel S, Rumpelt H-J, et al. Chromophobe cell renal carcinoma and its variants-a report on 32 cases. J Pathol 1988;155:277-287.

3 Kovacs A, Kovacs G. Low chromosome number in chromophobe renal cell carcinomas. Genes Chromosome Cancer 1992;4:267-268.

4 Iqbal MA, Akhtar M, Ali MA. Cytogenetic findings in renal cell carcinoma. Hum Pathol 1996;27:949-954.

5 Shuin T, Kondo K, Sakai N, et al. A case of chromophobe renal cell carcinoma associated with low chromosome number and microsatellite instability. Cancer Genet Cytogenet 1996;86:69-71.

6 Gunawan B, Bergmann F, Braun S, et al. Polyploidization and losses of chromosomes $1,2,6,10,13$, and 17 in three cases of chromophobe renal cell carcinomas. Cancer Genet Cytogenet 1999;110:57-61.

7 Speicher MR, Schoell B, du Manoir S, et al. Specific loss of chromosomes 1, 2, 6, 10, 13, 17, and 21 in chromophobe renal cell carcinomas revealed by comparative genomic hybridization. Am J Pathol 1994; 145:356-364.

8 Junker K, Weirich G, Amin MB, et al. Genetic subtyping of renal cell carcinoma by comparative genomic hybridization. Rec Res Cancer Res 2004; 162:169-175.

9 Schwerdtle RF, Störkel S, Neuhaus C, et al. Allelic losses at chromosomes 1p, 2p, 6p, 10p, 13q, 17p, and 21q significantly correlate with the chromophobe subtype of renal cell carcinoma. Cancer Res 1996; 56:2927-2930.

10 Bonsib SM, Lager DJ. Chromophobe cell carcinoma: analysis of five cases. Am J Surg Pathol 1990;14: 260-267.

11 Crotty TB, Farrow GM, Lieber MM. Chromophobe renal cell carcinoma: clinicopathologic features of 50 cases. J Urol 1995;154:964-967.
12 Akhtar M, Chantziantoniou N. Flow cytometric and quantitative image cell analysis of DNA ploidy in renal chromophobe cell carcinoma. Hum Pathol 1998; 29:1181-1188.

13 Iqbal MA, Akhtar M, Ulmer C, et al. FISH analysis in chromophobe renal-cell carcinoma. Diagn Cytopathol 2000;22:3-6.

14 Moch H, Sauter G, Gasser TC, et al. EGF-r gene copy number changes in renal cell carcinoma detected by fluorescence in situ hybridization. J Pathol 1998;184:424-429.

15 Gronwald J, Baur AS, Holtgreve-Grez $\mathrm{H}$, et al. Chromosomal abnormalities in renal cell neoplasms associated with acquired renal cystic disease: a series studied by comparative genomic hybridization and fluorescence in situ hybridization. J Pathol 1999; 187:308-312.

16 Verdorfer I, Hobisch A, Hittmair A, et al. Cytogenetic characterization of 22 human renal cell tumors in relation to a histopathological classification. Cancer Genet Cytogenet 1999;111:61-70.

17 Dijkhuizen T, van den Berg E, Störkel S, et al. Renal oncocytoma with $t(5 ; 12 ; 11)$, der(1)t(1;8) and add (19): 'true' oncocytoma or chromophobe adenoma? Int J Cancer 1997;73:521-524.

18 Zanssen S, Gunawan B, Fuzesi L, et al. Renal oncocytomas with rearrangements involving 11q13 contain breakpoints near CCND1. Cancer Genet Cytogenet 2004;149:120-124.

19 Crotty TB, Lawrence KM, Moertel CA, et al. Cytogenetic analysis of six renal oncocytomas and a chromophobe renal cell carcinoma, evidence that -Y, -1 may be a characteristic anomaly in renal oncocytomas. Cancer Genet Cytogenet 1992;61:61-66.

20 Meloni AM, Sandberg AA, deVere-White R. -Y, -1 as recurrent anomaly in oncocytoma. Cancer Genet Cytogenet 1992;61:108-109.

21 Lindgren V, Paner GP, Omeroglu A, et al. Cytogenetic analysis of a series of 13 renal oncocytomas. J Urol 2004;171:602-604.

22 Tickoo SK, Reuter VE, Amin MB, et al. Renal oncocytosis: a morphologic study of fourteen cases. Am J Surg Pathol 1999;23:1094-1101.

23 Al-Saleem T, Cairns P, Dulaimi EA, et al. The genetics of renal oncocytosis: a possible model for neoplastic progression. Cancer Genet Cytogenet 2004; 152:23-28.

24 Pavlovich CP, Walther MM, Eyler RA, et al. Renal tumors in the Birt-Hogg-Dubé syndrome. Am J Surg Pathol 2002;26:1542-1552.

25 Martignoni G, Eble JN, Brunelli M, et al. Chromophobe renal cell carcinoma: a clinicopathologic study of 100 cases. Mod Pathol 2003;16:161A.

26 Brunelli M, Eble JN, Zhang S, et al. Gains of chromosomes 7, 17, 12,16, and 20 and loss of Y occur early in the evolution of papillary renal cell neoplasia: a fluorescence in situ hybridization study. Mod Pathol 2003;16:1053-1059.

27 Brunelli M, Eble JN, Zhang S, et al. Metanephric adenoma lacks the gains of chromosomes 7 and 17 and loss of $\mathrm{Y}$ that are typical of papillary renal cell carcinoma and papillary adenoma. Mod Pathol 2003;16:1060-1063.

28 Hopman AHN, Ramaekers FCS, Raap AK, et al. In situ hybridization as a tool to study numerical chromosome aberrations in solid bladder tumors. Histochemistry 1988;89:307-316. 
29 Hopman AH, Voorter CE, Ramaekers FC. Detection of genomic changes in cancer by in situ hybridization. Mol Biol Rep 1994;19:31-44.

30 van den Berg E, van der Hout AH, Oosterhuis JW, et al. Cytogenetic analysis of epithelial renal-cell tumors: relationship with a new histopathological classification. Int J Cancer 1993;55:223-227.

31 Bugert P, Gaul C, Weber K, et al. Specific genetic changes of diagnostic importance in chromophobe renal cell carcinoma. Lab Invest 1997;76:203-208.

32 Akhtar M, Al-Sohaibani MO, Haleem A, et al. Flow cytometric DNA analysis of chromophobe cell carcinoma of the kidney. J Urol Pathol 1996;4:15-23.

33 Gerharz C-D, Moll R, Störkel S, et al. Establishment and characterization of two divergent cell lines derived from a human chromophobe renal cell carcinoma. Am J Pathol 1995;146:953-962.

34 Morell-Quadreny L, Gregori-Romero MA, LlombartBosch A. Chromophobe renal cell carcinoma: pathologic, ultrastructural, immunohistochemical, cytofluorometric, and cytogenetic findings. Pathol Res Pract 1996;192:1275-1281.
35 Balzarini P, Grigolato $\mathrm{P}$, Tardanico $\mathrm{R}$, et al. Multitechnical pathological diagnosis in chromophobe renal cell carcinoma. Oncol Rep 1999;6:295-299.

36 Brown JA, Takahashi S, Alcaraz A, et al. Fluorescence in situ hybridization analysis of renal oncocytoma reveals frequent loss of chromosomes $\mathrm{Y}$ and 1 . J Urol 1996;156:31-35.

37 Presti Jr JC, Moch H, Reuter VE, et al. Comparative genomic hybridization for genetic analysis of renal oncocytomas. Genes Chromosome Cancer 1996;17:199-204.

38 Polascik TJ, Cairns P, Epstein JI, et al. Distal nephron renal tumors: microsatellite allelotype. Cancer Res 1996;56:1892-1895.

39 Thrash-Bingham CA, Salazar $\mathrm{H}$, Freed JJ, et al. Genomic alterations and instabilities in renal cell carcinomas and their relationship to tumor pathology. Cancer Res 1995;55:6189-6195.

40 Herbers J, Schullerus D, Chudek J, et al. Lack of genetic changes at specific genomic sites separates renal oncocytomas from renal cell carcinomas. J Pathol 1998;184:58-62. 